\title{
SOTERIOLOGI MENURUT PAULUS SEBAGAI DASAR TRADISI BAGI PELAKSANAAN PENDIDIKAN AGAMA DALAM KONTEKS PLURALISME DI INDONESIA
}

\author{
Demianus Nataniel \\ Sekolah Tinggi Theologia Abdiel \\ demianusnataniel@gmail.com
}

\begin{abstract}
Ronald H. Cram said "the radical dialogue is an appropriate religious education model in pluralism context". He contended that the radical dialogue consists of the hospitality principles that goes beyond tolerance. Unfortunately, his argumentations have not been based on the biblical tradition. In this paper, therefore, I would like to propose soteriology of the cross in Paul's letters as a supporting tenet for implementing the radical dialogue in religious education, especially in Indonesian pluralism context. Based on the principles of soteriology of the cross in Paul's letters, Christian comunity in Indonesia will be provoked to implement the radical dialogue. In order to clarify how the principles of soteriology of the cross are approprieated with the concept of the radical dialogue, I will delineate an Indonesian pluralism context succintly and an appropriate model of religious education in the context respectively.
\end{abstract}

Keywords: Indonesian pluralism context, Paul's letter, radical dialogue, religious education, soteriology of the cross.

\section{Pendahuluan}

Dalam bukunya yang berjudul Beyond Tolerance, Ronald H. Cram memaparkan bagaimana melaksanakan pendidikan agama dalam konteks pluralisme. ${ }^{1}$ Bagi Cram pluralisme adalah kenyataan yang memang sudah disadari oleh banyak pihak di abad ke-21 ini. Namun demikian, persoalannya adalah bahwa kesadaran mengenai konteks pluralisme tidak membuahkan hasil apapun jika hanya sampai pada taraf kesadaran semata. Perlu ada yang harus dilakukan berkenaan dengan konteks ini mengingat kenyataan tersebut telah menghasilkan berbagai persoalan, termasuk konflik yang berdarah-darah. Untuk itu Cram menawarkan model pendidikan agama yang melampaui konsep toleransi dalam konteks pluralisme. Ia usulkan pendidikan agama dalam bentuk dialog yang bersifat radikal, yang didasarkan pada kesanggrahan (hospitality), yang digambarkan sebagai gerakan tari yang merupakan harmonisasi dari empati, kepedulian dan persahabatan. Menurutnya, dialog

\footnotetext{
${ }^{1}$ Ronald H. Cram, "Beyond Tolerance: Radical Dialogue in an Era of Expanding Religion”, dalam Memperlengkapi Bagi Pelayanan dan Pertumbuhan, peny. Richard R. Boehkle (Jakarta: BPK Gunung Mulia, 2002), 167-207.
} 
radikal seperti ini sesuai dengan apa yang digambarkan dalam perjumpaan antara Yesus dengan perempuan Kanaan dalam Matius 15:21-28.

Dengan berasumsi bahwa dialog radikal merupakan tantangan sekaligus harapan dalam pendidikan agama di tengah konteks masyarakat yang majemuk, tulisan ini hendak mengajukan sebuah dasar teologis biblis yang dapat mendukung konsep pendidikan sebagaimana yang diajukan oleh Cram, namun yang tidak disinggung sama sekali dalam tulisannya, yakni soteriologi dalam surat-surat Paulus. Dengan mengacu kepada pemahaman Paulus mengenai soteriologi, umat Kristen, khususnya di Indonesia, seharusnya berani melakukan dialog yang radikal, yang didasari pada kesanggrahan. Untuk sampai pada kesimpulan ini maka terlebih dahulu diulas konteks pluralisme dan permasalahannya di Indonesia. Setelah itu akan dipaparkan model pendidikan yang dibutuhkan dalam konteks pluralisme di Indonesia. Berdasarkan model yang dibutuhkan tersebut maka akan ditunjukkan bagaimana soteriologi yang dipahami Paulus dapat menjadi dasar bagi pendidikan agama yang menggunakan dialog radikal dalam pelaksanaannya.

\section{Pluralisme di Indonesia}

Bhinneka Tunggal Ika atau berbeda-beda tetapi tetap satu adalah motto yang ada pada lambang negara Indonesia, yakni Garuda Pancasila. Di balik motto tersebut terkandung adanya kesadaran bahwa masyarakat Indonesia adalah masyarakat yang majemuk. Kemajemukan di Indonesia terwujud antara lain dari adanya ragam suku dan agama. $^{2}$ Terlepas dari kemungkinan adanya perubahan di sana-sini terkait prosentase jumlah suku maupun agama, tetapi fakta yang tidak berubah hingga detik ini adalah adanya kemajemukan dalam kategori tersebut.

Kemajemukan suku dan agama yang ada di Indonesia sesungguhnya merupakan keindahan tersendiri, apalagi jika dikaitkan dengan fakta adanya deklarasi yang disebut dengan Sumpah Pemuda, yang diucapkan oleh kaum muda di Indonesia pada 28 Oktober 1928, yang menyatakan satu bangsa, satu bahasa, dan satu tanah air, yaitu Indonesia. Sebuah fakta yang sangat indah, yang telah ditorehkan oleh sekelompok anak bangsa ini. Fakta ini juga yang turut mendorong perjuangan bangsa Indonesia hingga meraih kemerdekaan pada 17 Agustus 1945. Dengan kata lain, kemajemukan atau pluralisme yang dimiliki oleh bangsa Indonesia telah dapat diatasi dengan menunjukkan persatuan dan

\footnotetext{
${ }^{2}$ Leo Suryadinata \& dkk., peny.. Indonesia's Population: Etnicity and Religion in a Changing
} Political Landscape (Singapore: Institute of Southeast Asian Studies: 2003). 
kesatuan bangsa Indonesia. Pertanyaannya adalah apakah keindahan ini dapat terus terjaga selamanya, ataukah sebaliknya pada suatu saat Indonesia akan mengalami nasib seperti Yugoslavia yang tercerai-berai melalui pertumpahan darah? Pertanyaan ini muncul bukan tanpa alasan. Ancaman disintegrasi bangsa berdasarkan potensi konflik yang diakibatkan kemajemukan yang ada di Indonesia sudah ada di hadapan mata. Berbagai peristiwa berdarah akibat ketidakmampuan sebagian masyarakat dalam mengatasi perbedaan bukan sekali dua kali terjadi. Rentetan peristiwa yang memakan banyak korban jiwa terus terjadi tiada henti. Pertanyaan berikutnya adalah apa yang dapat dilakukan agar bencana di depan mata tersebut dapat dihindari?

Sebelum sampai pada apa yang dapat dilakukan oleh gereja-gereja di Indonesia dalam mengatasi ancaman disintegrasi bangsa, termasuk konflik yang berdarah, perlu terlebih dahulu diungkapkan beberapa faktor yang menjadikan potensi persoalan di tengah konteks kemajemukan masyarakat Indonesia. Pertama adalah sejarah pertemuan agamaagama di Indonesia, khususnya Islam-Kristen yang diwarnai dengan banyak konflik. Konflik di tengah perjumpaan Islam-Kristen ini ditengarai oleh J.S. Aritonang akibat dari persoalan sejarah nasional dan global yang mengakibatkan berbagai kecurigaan di antara kedua kelompok agama tersebut di Indonesia. ${ }^{3}$ Kecurigaan ini tampaknya belum dapat diselesaikan sepenuhnya terlebih ketika banyak pihak memanfaatkan isu-isu SARA untuk meraih kekuasaan.

Kedua adalah persaingan di antara kelompok dalam agama itu sendiri. Konflik agama yang terjadi di Indonesia tidak hanya melibatkan kelompok agama yang berlainan, tetapi juga kelompok di dalam satu agama tertentu. Perbedaan dogma di antara kelompok dalam satu agama kerapkali dipakai sebagai alasan terjadinya konflik. Kasus perusakan rumah-rumah ibadah milik kelompok Ahmadiyah dalam tubuh umat Islam di Indonesia adalah salah satu contohnya. Persoalan tentang perebutan 'domba' di kalangan umat Kristen juga adalah contoh yang tidak boleh diabaikan. Pemahaman bahwa kelompok kami adalah yang benar dan yang lain harus musnah diakui atau tidak masih menguasai masyarakat beragama di Indonesia ini.

Ketiga adalah konflik antar suku yang tidak kalah sengitnya. Salah satu persoalan yang muncul di dalam relasi antar suku di Indonesia adalah apa yang disebut dengan

${ }^{3}$ Jan S. Aritonang, Sejarah Perjumpaan Kristen dan Islam di Indonesia (Jakarta: BPK Gunung Mulia, 2005), 593-594. 
stereotype etnic, yaitu sebuah fenomena pencirian secara negatif oleh satu kelompok masyarakat tertentu kepada kelompok masyarakat lainnya ${ }^{4}$.

Keempat, persoalan-persoalan sebagaimana disebutkan di atas dapat dikategorikan sebagai persoalan akibat kemajemukan secara horizontal, yang meliputi perbedaan suku dan agama di masyarakat Indonesia. Kemajemukan ini tidak lengkap menggambarkan kondisi masyarakat Indonesia tanpa memperhitungkan kemajemukan yang lainnya yakni kemajemukan berdasarkan kekuatan ekonomi dan kekuasaan. Tingkat kemiskinan dan pengangguran di Indonesia semakin menghebat setelah jatuhnya rezim Orde Baru, seiring dengan anjloknya kehidupan ekonomi makro negara Indonesia. Bahkan dapat dicurigai bahwa konflik horizontal yang terjadi di Indonesia, yang melibatkan kelompok suku dan agama, disisipi juga oleh konflik kepentingan ekonomi dan kekuasaan. Contohnya adalah konflik di Maluku Utara yang melibatkan kelompok Islam dan Kristen pada akhir tahun 1999-2000. Artinya, relasi antar suku maupun agama yang di dalamnya sudah mengandung potensi konflik menjadi berbahaya ketika persoalan ekonomi dan kekuasaan menyusup masuk di dalamnya. ${ }^{5}$

Persoalan sebagaimana disebutkan di atas bisa menjadi semakin rumit jika pemerintah yang berkuasa tidak kuat dan berwibawa. Pemerintah yang seharusnya berada di garda terdepan dalam menegakkan supremasi hukum tampaknya tidak selalu berfungsi sebagaimana mestinya. Demikian pula aparat keamanan yang seharusnya dapat melindungi masyarakat dalam menjalankan apa yang menjadi haknya, mereka tidak melakukan tugas yang seharusnya dilaksanakan. Kasus penutupan gereja-gereja di wilayah Kabupaten Bandung pada tahun 2005-2006 menunjukkan betapa aparat keamanan tidak menjalankan tugas yang semestinya mereka lakukan. Aparat keamanan berusaha menghindari tugasnya dengan mendorong pihak yang lemah untuk mengalah pada keingingan kelompok masyarakat dari kalangan mayoritas.

Kerumitan semakin sulit diselesaikan dengan adanya perkembangan teknologi komunikasi dan transportasi yang turut mendukung proses globalisasi. Dengan kemajuan teknologi komunikasi dan transportasi maka jarak antar wilayah di seluruh belahan dunia menjadi semakin dekat bahkan seolah tanpa pembatas. Di satu sisi kondisi ini membawa

\footnotetext{
${ }^{4}$ Koentjaraningrat, "Lima Masalah Integrasi Nasional", dalam Masalah-masalah Pembangunan: Suatu Antologi Antropologi Terapan, peny. Koentjaraningrat (Jakarta: LP3ES, 1982), 347.

${ }^{5}$ Lih. Chris Wilson, Ethno-Religious Violence in Indonesia: From Soil to God, 1-14; Christopher R. Duncan, Violence and Vengeance: Religious Conflict and Its Aftermath in Eastern Indonesia (Ithaca \& London: Cornell University Press, 2013), 47-74.; Gerry van Klinken, Communal Violence and Democratization in Indonesia: Small Town Wars (New York: Routledge, 2007), 107-123.
} 
harapan bagi terbukanya wawasan masyarakat mengenai kepelbagaian dan nilai-nilai yang dianut oleh masyarakat lainnya, tetapi di sisi lain perjumpaan dengan berbagai kebiasaan dan nilai-nilai lain dapat menghasilkan perasaan terancam, yang pada giliraannya tampil dalam hasrat untuk meniadakan orang lain yang berbeda.

Dari seluruh uraian di atas maka dapat disimpulkan bahwa pluralisme yang menjadi konteks masyarakat di Indonesia menantang setiap orang dan juga setiap kelompok masyarakat untuk memiliki identitas yang jelas tanpa harus menutup diri pada yang lain. Ketegangan antara keterbukaan dan penyataan jati diri inilah akan menjadi sasaran pendidikan yang harus dilakukan dengan terencana dan tersistematisasi agar potensi konflik yang dapat membahayakan dapat diarahkan menjadi sesuatu yang bermanfaat dan membangun.

\section{Sosialisasi dan Edukasi}

Pluralisme sebagai konteks masyarakat Indonesia saat ini menuntut setiap orang menyadari bahwa kepelbagaian dengan segala potensi konflik di dalamnya tidak dapat dihindari. Untuk itu gereja harus secara sadar dan terencana melakukan sosialisasi agar setiap anggotanya membiasakan diri dengan pluralisme. Dengan kata lain pendidikan agama dilakukan juga dalam bentuk mensosialisasikan nilai-nilai yang berkembang di tengah masyarakat majemuk sehingga kepelbagaian menjadi sebuah kesadaran yang menyatu dalam diri setiap orang Kristen.

Sebagaimana pernyataan Cram yang berpandangan bahwa kesadaran mengenai kemajemukan saja tidak cukup untuk mengubah keadaan maka diperlukan sebuah proses yang sadar dan terencana dapat memanfaatkan situasi dan kondisi yang ada dalam konteks pluralisme untuk menciptakan situasi dan kondisi yang lebih baik. ${ }^{6}$ Proses ini biasa disebut dengan edukasi, yakni sebuah proses untuk memperlengkapi setiap orang mengatasi persoalan yang ada dan menjadikannya sesuatu yang lebih baik.

Pendidikan yang terkait dengan proses sosialisasi dan edukasi dapat digambarkan sebagai sebuah peziarahan. Melalui hal itu pendidikan sebagai sebuah peziarahan maka relasi guru dan murid adalah kemitraan, sebagai yang sama-sama belajar untuk menghargai tradisi masing-masing dalam mengatasi situasi saat ini untuk tujuan yang lebih baik di masa depan. ${ }^{7}$ Selain itu sebagai sebuah peziarahan maka setiap orang yang terlibat

\footnotetext{
${ }^{6}$ Richard H. Cram, "Beyond Tolerance”, 167.

${ }^{7}$ Demianus Nataniel, "Paradigma Ziarah dalam Penafsiran Alkitab", Jurnal Abdiel 10, no. 2, (2018), 68.
} 
menempatkan diri sebagai para musafir yang bersama-sama dengan seluruh umat manusia lainnya melakukan perjalanan untuk menikmati keagungan ilahi dibalik hal-hal fisik yang dijumpainya. Pendidikan seperti ini akan mendorong baik guru dan murid menghargai lingkungannya yang dipenuhi dengan perbedaan, sekaligus siap untuk mengalami perubahan bersama. ${ }^{8}$

Pendidikan sebagai sebuah peziarahan menuntut adanya dasar tradisi yang jelas. Namun demikian tradisi yang dijadikan dasar haruslah tradisi yang memberi peluang setiap orang untuk mengalami perubahan ke arah yang jelas pula. Salah satu tradisi penting yang dimiliki oleh orang Kristen adalah keyakinan terhadap karya keselamatan Allah melalui Yesus sebagai Kristus yang disalibkan, dan yang kemudian dibangkitkan oleh Allah sebagaimana yang dinyatakan dalam Alkitab, khususnya surat-surat Paulus. ${ }^{9}$ Secara garis besar pemikiran Paulus mengenai karya keselamatan Allah melalui Yesus sebagai Kristus yang disalibkan mengandung empat hal penting yang saling berkaitan, yakni salib Kristus sebagai simbol perlawanan terhadap ketidakadilan, salib Kristus sebagai simbol rekonsiliasi, salib Kristus sebagai dasar hidup dalam kekudusan, dan salib Kristus sebagai bentuk pengosongan diri Allah yang Mahakuasa.

\section{Salib Kristus sebagai Simbol Perlawanan terhadap Ketidakadilan}

Beberapa ahli menyatakan bahwa peristiwa penyaliban Yesus oleh Paulus digunakan sebagai sebuah retorika dalam memperjuangkan gagasan-gagasan ideal yang dimilikinya. Dalam Inhabiting The Criciform God, Michael Gorman menyatakan bahwa Filipi 2:6-11 memuat perlawanan Paulus terhadap kebiasaan masyarakat Romawi yang cenderung mengejar hormat dan kekuasaan. ${ }^{10}$ Pemahaman bahwa peristiwa salib Yesus dipakai oleh Paulus sebagai retorika dalam melawan kekuatan Romawi juga sejalan dengan pemikiran Neil Elliot dan Richard A. Horsley. Dalam tulisannya yang berjudul The Anti-Imperial of the Cross, Elliot menunjukkan bagaimana peristiwa penyaliban Yesus digunakan untuk mengungkap kebobrokan pengadilan Romawi. ${ }^{11}$ Sementara itu dalam

\footnotetext{
${ }^{8}$ Ibid.

${ }^{9}$ James Dunn dan beberapa ahli lainnya memahami bahwa inti berita suka cita yang diwartakan oleh Paulus berpusat pada kematian dan kebangkitan Kristus. James D.G. Dunn, The New Perspective on Paul, revised edition (Grand Rapids, Michigan/ Cambridge, U.K.: Wm. B. Eerdmans Publishing Co., 2008), 264.

${ }^{10}$ Michael J. Gorman, Inhabiting the Cruciform God: Kenosis, Justification, and Theosis in Paul's Narrative Soterilogy (Grand Rapids, Michigan/ Cambridge, U.K.: William B. Eerdmans Publishing Company: 2009), 19.

${ }^{11}$ Neil Elliot, “Anti-Imperial Message of the Cross", dalam Paul and Empire: Religion and Power in Roman Imperial Society, peny. Richard H. Horsley (Harrisburg, Pennsylvania: Trinity Press International, 1997), 167-183.
} 
tulisannya yang berjudul Rhetoric and Empire-and 1 Corinthians, Horsley mengulas bagaimana Paulus memanfaatkan seni retorika yang dimilikinya untuk melawan isi dan bentuk seni retorika masyarakat Greko-Romawi itu sendiri, sekaligus struktur sosial yang dilayaninya. ${ }^{12}$ Dengan memilih pola kerasulannya yang tampaknya dipahami oleh Paulus sejalan dengan bagaimana Allah menghadirkan diri-Nya dalam diri Mesias yang disalib (1Kor. 4:8-13, 9:15-19), ia membalikkan pola dan visi seni retorika masyarakat GrekoRomawi yang cenderung bermegah berdasarkan kekuatan-kekuatan lahiriah untuk meraih kekuasaan dan hormat. Dengan menggunakan beberapa kata kunci yang dipakai sebagai alat propaganda pemerintah Romawi dalam meraih dukungan warga masyarakatnya, seperti kata euanggelion dan ekklessia, Paulus membongkar kegagalan dan janji-janji palsu pemerintah Romawi, sekaligus menunjukkan alternatif berita sukacita dan bentuk kehidupan sosial yang sesungguhnya diharapkan dan dibutuhkan oleh masyarakat pada waktu itu.

Bentuk perlawanan yang dilakukan oleh Paulus ini menurut Horsley bukanlah hal yang unik. ${ }^{13}$ Perlawanan terhadap kekuasaan Romawi yang dilakukannya berakar dari semangat apokaliptisme eskatologis Yahudi. Semangat apokaliptisme eskatologis Yahudi sebagaimana tercermin dalam berbagai literatur Yudaisme pada waktu itu berpangkal pada kesusahan yang dirasakan oleh bangsa Israel sebagai umat pilihan Allah, yang sedang dijajah oleh bangsa asing. Di dalamnya tercermin keyakinan bahwa Allah akan melakukan intervensi sejarah yang pada gilirannya akan menghancurkan kekuasaan kaum imperialis, membebaskan dan memperbarui seluruh aspek kehidupan Israel sebagai umat Allah, serta memberikan ganjaran bagi para martir untuk meraih kebangkitan dan hidup yang kekal. Namun demikian, Horsley juga menunjukkan perbedaan antara gagasan dalam retorika yang dilakukan oleh Paulus dengan pemahaman yang terkandung dalam semangat apokaliptisme eskatologis Yahudi. ${ }^{14}$ Perbedaan di antara keduanya terletak pada peran kematian dan kebangkitan Yesus, yang bagi Paulus dipahami sebagai telah dimulainya intervensi Allah dalam memenuhi janji-janji pembaharuan bagi Israel. Pemahaman ini menurut Horsley juga tidak unik sepenuhnya karena dalam salah satu naskah gulungan laut mati (Dead Sea Scrolls), telah muncul sosok yang disebut Guru Kebenaran, yang telah mempersiapkan jalan bagi pemenuhan janji-janji pemulihan Allah bagi umat yang setia kepada-Nya sebagaimana ditunjukkan oleh komunitas imamat Qumran. Pemenuhan dan

\footnotetext{
${ }^{12}$ Richard A. Horsley, "Rhetoric and Empire-And 1 Corinthians", dalam Paul and Politics, peny. Richard A. Horsley (Harrisburg, Pennsylvania: Trinity Press International, 2000), 72-102.

${ }^{13}$ Ibid., 97-102.

${ }^{14}$ Ibid.
} 
pemulihan yang dilakukan Allah bagi umat-Nya oleh Paulus antara lain dijelaskan dalam percakapan mengenai kebangkitan (1Kor. 15). Di sana Paulus memahami bahwa kebangkitan Yesus sebagai yang sulung dari antara orang-orang yang telah meninggal (1Kor. 15: 20-23). Perbedaan lainnya ialah bahwa dalam pemahaman Paulus, karya keselamatan yang Allah lakukan melalui Yesus Kristus tidak hanya memulihkan kehidupan orang-orang Israel saja, tetapi juga meliputi seluruh umat manusia, sebagaimana tercermin dalam Galatia 3:28.

Pemanfaatan peristiwa penyaliban Yesus sebagai sebuah retorika melawan kebiasaan yang berlaku di sekitarnya membawa sebuah implikasi setidaknya pada tiga hal. Pertama, karya penyelamatan Allah melalui Yesus yang disalibkan dan dibangkitan tidak hanya berbicara mengenai masalah kerohanian semata. Salib Yesus dan kebangkitan-Nya merupakan bagian dari upaya mengatasi persoalan-persoalan sosial di dunia ini. Hal ini penting mengingat umat Kristen seringkali memahami peristiwa salib Yesus hanya berhubungan dengan masalah kerohanian, serta mengabaikan situasi sosial dan politik yang melatarbelakangi mengapa Yesus sampai mati di kayu salib. Sebagaimana Yohanes 1:14 berkata bahwa firman itu telah menjadi manusia maka mutlak bagi umat Kristen saat ini melihat peristiwa salib Yesus sebagai peristiwa yang sungguh-sungguh manusiawi, di samping tetap meyakiniakan kehadiran Allah yang membangkitkan Yesus. Pengabaian konteks sosial dan politik yang melatarbelakangi mengapa Yesus disalibkan dapat membuat umat Kristen terjebak dalam kehidupan keagamaan yang tidak seimbang, yang sebenarnya dikritik oleh Yesus sendiri. Pengabaian itu dapat membawa gereja asyik dengan dirinya sendiri dan mengabaikan tanggung jawab sosial bagi masyarakat di sekitarnya.

Kedua, dengan memandang penyaliban Yesus sebagai peristiwa yang sungguhsungguh manusiawi maka umat Kristen harus memahami peristiwa penyaliban Yesus tidak langsung pada situasi yang terjadi di bukit Golgota, tetapi mulai dari pergumulanpergumulannya sejak di Galilea. Dengan demikian gereja diarahkan untuk memperhatikan dengan seksama sikap Yesus yang sesungguhnya terhadap ketidakadilan yang terjadi. Sikap Yesus dalam hal ini adalah melawan dengan segenap jiwa dan raga. Ajaran Yesus kepada murid-muridnya untuk mengasihi Allah dengan cara mengasihi sesama manusia diterjemahkan antara lain dengan berjuang melawan ketidakadilan yang terjadi sampai mati di kayu salib. Hal ini juga penting mengingat gereja seringkali menerima berbagai bentuk ketidakadilan dengan berlindung di balik salib Yesus. 
Peristiwa saat penangkapan dan juga penyaliban yang kesannya menggambarkan sikap Yesus tanpa perlawanan ditafsirkan sebagai sikap menerima segala ketidakadilan begitu saja dengan harapan mendapatkan ganjaran kehidupan di sorga setelah kematian. Penafsiran seperti inilah yang mendorong munculnya tuduhan banyak pihak, khususnya kaum feminis yang menyatakan bahwa teologi salib telah turut melanggengkan kekerasan terhadap kaum yang lemah, khususnya kaum perempuan. Dengan memahami penyaliban Yesus sebagai konsekuensi dari sikapnya dalam memperjuangkan keadilan maka tidak ada alasan bagi gereja saat ini untuk menerima begitu saja ketidakadilan yang ada. Gereja harus menolaknya tanpa kompromi.

Dalam hal pendidikan agama di tengah konteks pluralisme, pandangan Paulus mengenai karya keselamatan Allah melalui Yesus sebagai Kristus yang mati dan bangkit seharusnya mendorong gereja menyadari secara utuh konteks pergumulannya, sekaligus berusaha untuk mengatasinya. Pemanfaatan soteriologi salib sebagai retorika dalam melawan bentuk ketidakadilan dapat dipahami sebagai usaha yang kreatif dan tidak kenal lelah gereja dalam mengatasi persoalan-persoalan yang ada. Hal ini sejalan dengan pemikiran Cram yang menyatakan bahwa kesadaran akan persoalan ataupun konteks yang terjadi tidak akan bermanfaat tanpa adanya upaya sadar dan sengaja dalam mengatasinya.

\section{Salib Kristus sebagai Simbol Rekonsiliasi}

Berdasarkan penelusuran terhadap teks-teks dari surat-surat yang dianggap sungguh-sungguh ditulis oleh Paulus, yakni 1 \& 2 Korintus, Roma, 1 Tesalonika, Galatia, Filipi dan Philemon, Anthony J. Tambasco menyimpulkan bahwa menurut Paulus penebusan yang dikerjakan Allah dilakukan melalui kematian dan kebangkitan Yesus, serta dicurahkannya Roh Kudus. ${ }^{15}$ Sedangkan tujuan penebusan itu sendiri adalah rekonsiliasi atau pendamaian antara Allah dan manusia, serta manusia dengan sesama ciptaan Allah lainnya. ${ }^{16}$

Untuk sampai pada kesimpulan di atas, Tambasco memulainya dengan membahas teologi penebusan yang diusung oleh Anselmus, yang dalam kenyataannya sangat mempengaruhi pemahaman gereja selama ini. Intisari pemikiran Anselmus adalah bahwa kematian Yesus merupakan pengganti hukuman yang seharusnya dijalani manusia dalam

${ }^{15}$ Anthony J. Tambasco, A Theology of Atonement and Paul's Vision of Christianity, Zacchaeus Studies: New Testament, A Michael Glazier Book (Collegeville, Minnesota: The Liturgical Press, 1991), 6193.

${ }^{16}$ Ibid, 94-114. 
rangka mempertahankan keadilan Allah. Dan ternyata, pemikiran ini menurut Tambasco tidak sesuai dengan teologi penebusan yang dimiliki oleh Paulus. ${ }^{17}$

Menurut Tambasco, Paulus memahami keadilan Allah dan murka Allah sebagai dua sisi dari aktivitas Allah yang menyelamatkan. ${ }^{18}$ Seiring dengan itu Tambasco meyakini bahwa Paulus juga memahami ada tiga alasan yang saling berkaitan sehingga penebusan yang dilakukan Allah sungguh-sungguh diperlukan. Tiga alasan yang dimaksud adalah dosa yang menguasai dunia, kematian sebagai akibat dari dosa, serta hukum Taurat yang tidak dapat menyelamatkan manusia. ${ }^{19}$ Berdasarkan ketiga alasan ini maka penebusan Allah mutlak dibutuhkan oleh manusia. Salah satu hal penting yang ditekankan oleh Tambasco adalah bahwa dosa bukanlah terutama serangkaian perbuatan yang dianggap melanggar hukum, tetapi lebih merupakan kondisi atau keadaan manusia baik secara pribadi maupun komunal. Dosa yang menguasai dunia ini membuat hukum Taurat yang sesungguhnya baik sekalipun tidak mampu menyelamatkan manusia. Kematian sebagai wujud terpisahnya relasi manusia dengan Allah secara total mengakibatkan rusaknya relasi-relasi yang dibangun oleh manusia. Oleh karenanya maka dosa selalu berdimensi sosial, berkaitan dengan relasi manusia dengan sesamanya manusia, bahkan sesama ciptaan Allah lainnya. Dengan demikian, penebusan Allah juga berdimensi sosial.

Pemahaman bahwa keselamatan yang dilakukan Allah melalui kematian dan kebangkitan Kristus adalah upaya rekonsiliasi juga dimiliki oleh Michael J. Gorman. Menurutnya, untuk merekonstruksi pemahaman Paulus pengenai pembenaran yang dinyatakan dengan hidup dalam kematian dan kebangkitan bersama Kristus dibutuhkan terlebih dahulu pemahaman mengenai makna perjanjian dan pembenaran. ${ }^{20}$ Walter Brueggeman mengatakan bahwa bagi Israel, ikatan perjanjian dirumuskan dalam sebuah tuntutan untuk mengasihi sesama sebagai penyataan mengasihi Allah. ${ }^{21}$ Dalam Perjanjian Lama, tuntutan ini tidak hanya berlaku bagi Israel, tetapi juga bagi seluruh umat manusia sebagaimana dinyatakan dalam Mikha 6:8. Gagasan serupa juga dinyatakan dalam pengajaran Yesus di Injil-injil (Mrk. 12:28-34; Mat. 22:36-40; Luk. 10-25-28). Persoalannya adalah bahwa apa yang seharusnya terjadi sebagai pemenuhan tuntutan Perjanjian, dirusak oleh apa yang disebut dengan dosa. ${ }^{22}$

\footnotetext{
${ }^{17}$ Ibid, 11-18.

${ }^{18}$ Ibid, 19-34.

${ }^{19}$ Ibid, 35-60.

${ }^{20}$ Michael J. Gorman, Inhabiting the Cruciform God, 48.

${ }^{21}$ Walter Brueggemann, Theology of the Old Testament: Testimony, Dispute, Advocacy (Minneapolis: Fortress Press, 1997), 160-161.

${ }^{22}$ Ibid
} 
Menurut Gorman, Paulus memahami bahwa dosa memiliki dua dimensi. Yang pertama adalah kuasa yang darinya manusia membutuhkan pembebasan dan penebusan (Rm. 3:9,24; 6:7; Gal. 3:22), dan yang kedua adalah pelanggaran-pelanggaran yang membutuhkan pengampunan (Rm. 1:18-32; 3:10-18,25). ${ }^{23}$ Pembenaran dalam hal ini memuat pengampunan dan pembebasan dari dosa yang di dalamnya juga berarti proses transformasi perilaku dan relasi manusia dengan sesamanya. Pembenaran dapat dikatakan juga sebagai pembaruan relasi perjanjian, yakni kesetiaan kepada Allah dan persekutuan kasih dengan sesama, yang di dalamnya juga memuat harapan akan mendapatkan ganjaran pada penghakiman terakhir. Dengan kata lain, pembenaran merupakan sebuah rekonsiliasi sebagaimana tercermin dalam Roma 5:1-11 dan 2 Korintus 5:14-21.

Dengan memahami bahwa tujuan karya penyelamatan Allah adalah rekonsiliasi maka penting bagi gereja mencermati berbagai persoalan sosial dalam bentuk relasi-relasi yang rusak, baik yang terjadi antar sesama manusia maupun dengan ciptaan Allah lainnya. Dalam konteks pluralisme di Indonesia, salah satu persoalan yang penting untuk dicermati adalah luka-luka yang terlanjur menganga akibat berbagai konflik berdarah yang terjadi. Persoalannya adalah bahwa banyak konflik yang terjadi di Indonesia seringkali berakhir tanpa penyelesaian yang jelas. Di satu sisi seringkali tidak ada kejelasan siapa yang bersalah atau yang bertanggung jawab. Ironisnya, masing-masing pihak kerapkali mengaku diri sebagai korban, walaupun faktanya mereka sendiri yang melakukan kekerasan hingga menghasilkan banyak korban jiwa.

Dengan menempatkan soteriologi salib sebagai dasar tradisi maka pendidikan agama diarahkan juga untuk mengatasi akibat-akibat buruk dari konflik yang terjadi. Pendidikan yang seperti ini bertujuan bukan hanya sekedar menutupi atau bahkan menyembuhkan luka yang ada, tetapi juga menjadikannya mampu berkreasi secara produktif. Untuk itu pengalaman pahit akibat konflik berdarah yang pernah dialami tidak boleh dilupakan begitu saja, melainkan harus diingat dan dijadikan pelajaran untuk meraih kehidupan bersama yang lebih baik.

\section{Salib Kristus dan Hidup Kudus}

Walaupun Paulus tidak mengutip secara terbuka "Kuduslah kamu sebab Aku kudus" (Im. 11:44-45;19:2), tetapi ada banyak bukti bahwa sebagai seorang Yahudi yang

${ }^{23}$ Michael J. Gorman, Inhabiting the Cruciform God, 49-51. 
saleh dia mengetahui dan merenungkan makna teks tersebut. ${ }^{24}$ Paulus memahami bahwa kekudusan didasari sepenuhnya pada Injil atau berita sukacita yang diwartakannya, khususnya keyakinannya bahwa Yesus sebagai Mesias yang disalib dan sebagai Anak Allah. Yesus sebagai Mesias yang disalib juga merupakan penyataan kekudusan Allah Bapa. $^{25}$

Orang-orang yang percaya kepada Mesias yang disalib, dipahami oleh Paulus sebagai orang-orang yang dibenarkan, sekaligus dipanggil dengan kuasa Roh Kudus untuk disalibkan bersama Kristus. Roh Kudus yang dimaksud di sini diyakini oleh Paulus sebagai Roh atau kekuatan yang keluar baik dari Allah Bapa dan Anak. ${ }^{26}$ Artinya, pemahaman Paulus mengenai kekudusan manusia didasarkan pada salib Kristus, yang pada gilirannya mencerminkan relasi Allah Tritunggal. ${ }^{27}$

Pada seluruh bagian 1 Korintus terdapat tiga dimensi kekudusan yang diharapkan Paulus dapat diwujudkan oleh jemaat tersebut, yakni menghindari percabulan dan hidup dalam perilaku seksual yang benar (1Kor. 5:1-13; 6:12;7:1-40), menghindari penyembahan berhala dan menunjukkan totalitas kesetiaan pada Yesus (1Kor. 10:1-22), dan di atas semuanya itu adalah menghindari cara hidup yang hanya melayani diri sendiri, serta menjalani hidup seperti Kristus yang menyerahkan dirinya untuk dapat berarti bagi sesama (1Kor. 13:5; 8:1-13; 9:1-26; 10:23-11:1; 14:1-40). ${ }^{28}$

Hidup sebagaimana Kristus lakukan antara lain dinyatakan dengan memperhatikan terutama jemaat yang lemah (1Kor. 11:17-34; 12:14-26), menghargai rasul-rasul yang menampilkan kerendahan hati dan tetap bermegah dalam kelemahan (1Kor. 4:1-13), serta berkomitmen untuk melawan ketidakadilan (1Kor. 6:1-11). ${ }^{29}$ Kekudusan seperti ini dipahami sebagai perlawanan terhadap sikap hidup dan perilaku umum masyarakat Romawi yang cenderung mengejar kekuasaan dan hormat, serta lebih menghargai mereka yang kuat dan kaya. Oleh sebab itu bagi Paulus, kehidupan orang-orang kudus berbeda dari mereka yang tidak mengenal Allah. Kekudusan berarti perlawanan terhadap kehidupan duniawi (1Tes. 5:4-11; Rm. 12-13) tanpa harus melarikan diri dari kehidupan di dunia ini (1Kor. 5:9-10). ${ }^{30}$

\footnotetext{
${ }^{24}$ Ibid., 105.

${ }^{25}$ Ibid., 106.

${ }^{26}$ Ibid.

${ }^{27}$ Ibid.

${ }^{28}$ Ibid., 112-113.

${ }^{29}$ Ibid., 110.

${ }^{30}$ Ibid.
} 
Sementara itu dalam 1 Korintus 1:18:2:5 Paulus menyatakan secara tegas bahwa Kristus yang disalib adalah kekuatan dan hikmat Allah (1Kor. 1:24). Paulus tampaknya menyimpulkan bahwa Kristus yang disalib menyatakan dan mendefinisikan kehadiran Allah yang sesungguhnya. Berbeda dengan pandangan Yudaisme yang memahami bahwa kekuatan dan belas kasihan sebagai dua hal yang bertentangan, Paulus menghadirkan keduanya bagaikan sebuah komposisi musik yang harmonis. Kekuatan Allah terletak dalam hikmat-Nya yang penuh belas kasihan. ${ }^{31}$

Dari seluruh uraian di atas maka Paulus sesungguhnya meneguhkan kembali sebagian makna kekudusan dalam tradisi Yahudi, yakni menjauhkan diri dari penyembahan berhala dan kecemaran dalam hal seksualitas, tetapi juga mengoreksi sebagian di antaranya, yakni aturan yang berkenaan dengan eksklusivitas Israel sebagai umat Allah. Lebih dari itu, Paulus kemudian mengusulkan konsep kekudusan yang berpusat pada anugerah Allah bagi seluruh umat manusia yang ditandai dengan kehidupan yang dituntun oleh Roh Kudus untuk dapat menghadirkan diri sebagai Kristus yang disalibkan, dan yang juga adalah penyataan dan gambar Allah yang hidup. Kekudusan seperti ini pada gilirannya juga melawan perilaku yang hanya memuaskan hawa nafsu dan yang hanya berorientasi pada kepentingan diri sendiri.

Kesadaran terhadap karya penyelamatan Allah melalui Kristus yang disalib dengan demikian mendorong orang kristen untuk menunjukkan hidup yang berkualitas. Kualitas kehidupan yang diharapkan di sini adalah kehidupan sebagaimana Yesus jalani. Kehidupan ini mungkin saja dianggap menyimpang dari kebiasaan masyarakat umumnya, yang cenderung egois dan hanya mementingkan dirinya sendiri. Inilah kehidupan yang benarbenar berarti.

Kesadaran akan panggilan hidup kudus sebagaimana disebutkan di atas ternyata tidak dapat dilepaskan dari pemahaman akan kehadiran Allah sebagai Bapa, kasih dan kesetiaan Yesus, serta kuasa Roh Kudus. Artinya, kekudusan ini didasarkan pada tiga pribadi Allah yang berelasi secara khas dalam menyatakan kasih dan kuasanya. Dengan kata lain pada dasarnya kekudusan selalu bersifat relasional. Kekudusan bukan masalah pribadi semata. Kekudusan adalah persoalan bagaimana setiap orang Kristen berelasi dengan siapapun, baik dengan sesama orang Kristen maupun dengan yang bukan Kristen. Tujuan dari relasi-relasi ini adalah membangun sebuah kebersamaan yang bermanfaat bagi dunia ini.

${ }^{31}$ Ibid., 118. 
Makna kekudusan yang dibangun berdasarkan karya keselamatan Allah melalui Mesias yang disalib dengan sendirinya mendorong orang Kristen untuk dapat berelasi dan bekerja sama dengan siapapun. Dengan demikian maka upaya pembangunan gereja sebagai tubuh Kristus tidak semata-mata untuk gereja itu sendiri, tetapi agar gereja mampu bekerja sama dengan siapapun yang berada di luar dirinya. Oleh sebab itu pendidikan agama yang dilakukan oleh gereja seharusnya juga melayani tujuan ini.

\section{Pengosongan Diri}

Gorman berpendapat bahwa Filipi 2:6:-11 bukan hanya dimanfaatkan Paulus sebagai sebuah retorika dalam melawan kekuasaan Romawi, tetapi juga merupakan narasi utama pemikiran Paulus mengenai karya keselamatan Allah melalui kenosis atau pengosongan diri untuk mengambil rupa seorang manusia. ${ }^{32}$ Berdasarkan strukturnya, Filipi 2:6-11 berisi dua bagian penting yang tak terpisahkan, yakni Filipi 2:6-8 dan Filipi 2:9-11. Inti pembicaraan dalam Filipi 2:6-8 adalah penyerahan diri Kristus sebagai hamba. Pola penuturannya adalah "walaupun (x) tidak (y) melainkan (z)". Pola penuturan ini bagaikan gerakan ke bawah dan mendalam (downward mobility). Joseph Hellerman menggambarkannya sebagai sebuah "cursus pudorum" atau sebuah peralihan tanpa aib dari yang luhur menuju sesuatu yang berada di bawah, yang dirancang untuk melawan pola kelompok elit Romawi yang cenderung berlomba-lomba mengejar hormat dan kekuasaan. $^{33}$

Berkaitan dengan kenosis atau tindakan pengosongan diri Allah, Gorman memahami bahwa Filipi 2:6-11 merupakan petunjuk bahwa Paulus juga meyakini adanya pra eksistensi Kristus. ${ }^{34}$ Beberapa penafsir menolak pemahaman ini. Salah satu di antaranya adalah James Dunn. ${ }^{35}$ Namun demikian Gorman mengajukan tiga hal untuk mendukung pemahaman pra eksistensi Kristus dan kesetaraannya dengan Allah. Pertama, frase "dalam rupa Allah" (en morfe theou) memiliki tiga makna penggambaran Kristus, yakni: yang memiliki status en morfe theou, yang memiliki relasi paralelisme antithesis dengan rupa seorang hamba, dan yang secara langsung dijelaskan oleh anak kalimat hina theō yang mengikutinya. Kedua, anak kalimat to einai isa theō harus dipahami sebagai

\footnotetext{
${ }^{32}$ Gorman, Inhabiting the Cruciform God, 12.

${ }^{33}$ Joseph H. Hellerman, Reconstructing Honor in Roman Philippi: Cermen Christi as Cursus Pudorum, Cambridge: Cambridge University Press, 2005), 130. Demianus Nataniel, "Kenosis dan Koinonia", dalam Berakar dan Bertumbuh dalam Dia, peny. Besly T. J. Messakh (Jakarta: BPK, 2017), 82.

${ }^{34}$ Michael J. Gorman, Inhabiting the Cruciform God, 18.

${ }^{35}$ James D.G. Dunn, "Christ, Adam, and Preexistence", dalam Where Christology Began, peny. Ralph P. Martin \& Brian J. Dodd (Louisville: Westminster John Knox, 1998), 78-79.
} 
penjelasan terhadap frase morfe theō dan dapat diterjemahkan menjadi "kesetaraannya dengan Allah". Ketiga, ungkapan oukh harpagmon hegeseto mengacu kepada sesuatu yang telah ada, sehingga ketika dikaitkan dengan kehadiran Kristus maka dapat disimpulkan adanya pra eksistensi Kristus. ${ }^{36}$

Dari uraian di atas dapat diartikan bahwa jika Kristus yang disalibkan merupakan pengosongan diri atau kenosis Allah maka asumsi dasarnya adalah pemahaman adanya pra eksistensi Kristus. Pengosongan diri atau kenosis dengan demikian merupakan cara radikal yang diambil Allah bukan hanya untuk menyatakan diri-Nya, tetapi juga untuk memperbarui relasi-relasi yang rusak akibat dosa. Penyataan diri Allah dengan demikian tidak dapat dipisahkan dari karya keselamatan yang dilakukan-Nya. Kehadiran-Nya bersifat fungsional.

Pengosongan diri atau kenosis dapat dikatakan sebagai wujud kesanggrahan Allah. Dengan kenosis Allah bukan hanya menghadirkan contoh yang kasat mata bagi manusia, tetapi juga berani mengambil risiko, sekaligus yang memungkinkan-Nya berdialog secara terbuka, berempati, bersahabat, dan menunjukkan kepedulian-Nya terhadap manusia dan dunia yang dikuasai dosa. Tanpa keberanian untuk mengambil risiko maka dialog yang terbuka, yang didasari oleh empati, persahabatan, dan kepedulian tidak akan pernah dapat terjadi. Inilah panggilan hidup bagi setiap orang Kristen. Ganjaran Allah dengan mengaruniakan "nama di atas segala nama", dan sebutan "Tuhan" terhadap kasih dan kesetiaan yang ditunjukkan oleh Yesus dengan mati di kayu salib sebagai akibat dari bela rasanya kepada manusia yang hidup dalam pergumulan merupakan petunjuk bahwa apa yang dilakukan Yesus adalah jalan hidup yang harus ditempuh oleh orang-orang Kristen. Orang Kristen harus berani menanggung risiko apapun yang akan terjadi dalam menyatakan jati dirinya atau kesanggrahannya. Jika dikaitkan dengan konteks pluralisme maka pengosongan diri atau kenosis yang telah ditunjukkan Allah merupakan dasar segala tindakan gereja, termasuk pendidikan agama yang harus dilaksanakannya.

\section{Kesimpulan}

Pluralisme adalah konteks kehadiran gereja-gereja di Indonesia. Konteks ini mengandung tantangan sekaligus harapan bagi gereja dalam membangun masyarakat yang lebih baik. Untuk itu gereja melalui pendidikan agama harus memperlengkapi anggotaanggotanya untuk dapat membiasakan diri dengan konteks pluralisme sekaligus

${ }^{36}$ Michael J. Gorman, Inhabiting the Cruciform God, 18-20. 
memanfaatkannya dalam menata kehidupan bersama yang lebih baik. Pendidikan ini adalah pendidikan yang mengajak orang-orang Kristen dapat berjalan dan bekerja sama sebagai para musafir yang tengah melakukan perjalanan untuk menikmati persekutuan dengan Allah dan dengan seluruh ciptaan-Nya.

Sebagai konteks pendidikan, pluralisme menantang dan memberi kesempatan setiap orang berjumpa dan berdialog. Dialog yang dimaksud adalah dialog yang sungguhsungguh mendorong dan memberi peluang semua pihak untuk melakukan perubahan ke arah yang lebih baik. Dialog ini disebut oleh Cram sebagai dialog yang radikal. Dialog yang radikal sebagai pola pendidikan agama yang diusulkan oleh Cram ini mendapat dasar pijakan yang jelas dalam pemikiran Paulus mengenai karya keselamatan yang dilakukan Allah. Dalam pemikiran Paulus, karya keselamatan dilakukan Allah melalui Kristus yang disalibkan. Dalam pemikiran Paulus ini terkandung prinsip-prinsip yang mendukung dilaksanakannya dialog yang radikal, yakni prinsip perjuangan melawan ketidakadilan, membangun relasi yang harmonis, hidup dalam kekudusan, dan pengosongan diri. Empat prinsip dalam soteriologi salib Paulus ini mengemban amanat agung bagi gereja untuk berani mengambil risiko dalam berdialog untuk perubahan bersama kearah yang lebih baik.

\section{Kepustakaan}

Aritonang, J.S. Sejarah Perjumpaan Kristen dan Islam di Indonesia. Jakarta: BPK Gunung Mulia, 2005.

Brueggemann, W. Theology of the Old Testament: Testimony, Dispute, Advocacy. Minneapolis: Fortress Press, 1997.

Cram, Ronald H. "Beyond Tolerance: Radical Dialogue in an Era of Expanding Religion", dalam Memperlengkapi Bagi Pelayanan dan Pertumbuhan, peny. Richard H. Boehkle. Jakarta: BPK Gunung Mulia, 2002.

Duncan, Christopher R. Violence and Vengeance: Religious Conflict and Its Aftermath in Eastern Indonesia. Ithaca \& London: Cornell University Press, 2013.

Dunn, James D. G. The New Perspective on Paul, revised edition. Grand Rapids, Michigan/ Cambridge, U.K.: Wm. B. Eerdmans Publishing Co., 2008.

"Christ, Adam, and Preexistence" dalam Where Christology Began, peny. Ralph P. Martin \& Brian J. Dodd. Louisville: Westminster John Knox, 1998.

Eliade, M. Encyclopedy of Religion. New York: Macmillan, 1987.

Elliot, Neil. "Anti Imperial Message of the Cross", dalam Paul and Empire: Religion and Power in Roman Imperial Society, peny. Richard A. Horsley, Harrisburg. Pennsylvania: Trinity Press International, 1997. 
Gorman, Michael J. Inhabiting the Cruciform God: Kenosis, Justification, and Theosis in Paul's Narrative Soteriology. Grand Rapids, Michigan/ Cambridge, U.K.: Wm. B. Eerdmans Publishing Co, 2009.

Halstead, Elizabeth S, dkk. peny. dalam Dwelling With Philippians: A Conversation with Scripture through Image and Word. Grand Rapids, Michigan/ Cambridge, U.K.: Wm. B. Eerdmans Publishing Co, 2010.

Hellerman, J. H. Reconstructing Honor in Roman Philippi. Cambridge: Cambridge University Press, 2005.

Horsley, Richard A. "Rhetoric and Enpire-And 1 Corinthians" dalam Paul and Politics, peny. Richard A. Horsley. Harrisburg, Pennsylvania: Trinity Press International, 2000 .

Koentjaraningrat. "Lima Masalah Integrasi Nasional", dalam Masalah-masalah Pembangunan: Suatu Antologi Anthropologi Terapan, peny. Koentjaraningrat. Jakarta: LP3ES, 1982.

MacCormack, S. "Loca Sancta: The Organization of Sacred Topography in Late Antiquity" dalam Blessings of Pilgrimage, peny. Robert Ousterhout. Urbana \& Chicago: University of Illinois Press, 1990.

Nataniel, D. "Kenosis dan Koinonia", dalam Berakar dan Bertumbuh dalam Dia, peny. Besly T. J. Messakh. Jakarta: BPK, 2017.

"Paradigma Ziarah dalam Penafsiran Alkitab", Jurnal Abdiel 10, No. 2, 2018.

Suryadinata, Leo, dkk. peny. Indonesia's Population: Etnicity and Religion in a Changing Political Landscape. Singapore: Intitute of Southeast Asian Studies, 2003.

Tambasco, Anthony J. A Theology of Atonement and Paul's Vision of Christianity. Zacchaeus Studies: New Testament, A Michael Glazier Book, Collegeville, Minnesota: The Liturgical Press, 1991.

Van Klinken, G. Communal Violence and Democratization in Indonesia: Small Town Wars. New York: Routledge, 2007.

Wilson, C. Ethno-Religious Violence in Indonesia: From Soil to God. London \& New York: Routledge, 2008. 